\title{
Cereals, calories and change: exploring approaches to quantification in Indus archaeobotany
}

\author{
J. Bates ${ }^{1,2} \cdot$ C.A. Petrie ${ }^{1,3} \cdot$ R.N. Singh ${ }^{4}$
}

Received: 23 March 2016 / Accepted: 10 March 2017 / Published online: 10 April 2017

(C) The Author(s) 2017. This article is published with open access at Springerlink.com

\begin{abstract}
Several major cereal groups have been identified as staples used by the pre-urban, urban and post-urban phase populations of the Indus Civilisation (3200-1500 BCE): wheat, barley, a range of small hulled millets and also rice, though their proportional exploitation is variable across space and over time. Traditional quantification methods examine the frequency, intensity and proportionality of the use of these crops and help ascertain the 'relative importance' of these cereals for Indus populations. However, this notion of 'importance' is abstracted from the daily lives of the people using these crops and may be biased by the differential production (as well as archaeological survival) of individual cereals. This paper outlines an alternative approach to quantifying Indus cereals by investigating proportions of calories. Cereals are predominantly composed of carbohydrates and therefore provided much of the daily caloric intake among many late Holocene farming populations. The four major cereal groups cultivated by Indus farmers, however, vary greatly in terms of calories per grain, and this has an impact on their proportional input to past diets. This paper demonstrates that, when converted
\end{abstract}

Electronic supplementary material The online version of this article (doi:10.1007/s12520-017-0489-2) contains supplementary material, which is available to authorized users.

J. Bates

jb599@cam.ac.uk

1 McDonald Institute for Archaeological Research, University of Cambridge, Downing Street, Cambridge CB2 3ER, UK

2 Selwyn College, University of Cambridge, Cambridge CB3 9DQ, UK

3 Division of Archaeology, University of Cambridge, Downing Street, Cambridge CB2 3DZ, UK

4 Department of AIHC and Archaeology, Banaras Hindu University, Varanasi, India to proportions of calories, the perceived 'importance' of cereals from five Indus sites changes dramatically, reducing the role of the previously dominant small hulled millet species and elevating the role of Triticoid grains. Although other factors will also have affected how a farmer perceived the role and importance of a crop, including its ecological tolerances, investments required to grow it, and the crop's role in the economy, this papers suggests that some consideration of what cereals meant in terms of daily lives is needed alongside the more abstracted quantification methods that have traditionally been applied.

Keywords Indus Civilisation · Plant macroremains $\cdot$ South Asia $\cdot$ Bronze age $\cdot$ Calories $\cdot$ Quantification

\section{Introduction}

The role of agriculture in South Asia's Indus Civilisation (32001300 BCE) (Table 1, Fig. 1) is a growing area of research. As in most complex societies, food production was integral to all aspects of the society and economy of the Indus Civilisation, potentially impacting upon its development and decline (Madella and Fuller 2006), and the interaction between cities and their hinterlands (Weber 2003; Wright 2010). It has thus been incorporated into models of its social organisation (e.g. Wheeler 1950; Fairservis 1967; Kenoyer 1997, 2000; Wright 2010). Since the 1990s, the number of sites with archaeobotanical datasets has increased to the point where an overall picture of Indus agriculture can be outlined (e.g. Fuller and Madella 2002). However, despite this growing corpus of data, many researchers seeking to characterise Indus agriculture still refer to a core-periphery model, which was developed using data from the site of Harappa (Weber 1992, 1997, 2003), combined with datasets several sites in from Gujarat (Weber 1989, 1991; Reddy 1994, 1997, 2003). A different pattern has been 
Table 1 Chronology of the Indus Civilisation (after Possehl 2002: 29)

\begin{tabular}{|c|c|c|}
\hline Stage & Dates & Regional phases \\
\hline Early Harappan & $3200-2600 \mathrm{BCE}$ & $\begin{array}{l}\text { Amri-Nal } \\
\text { Kot Diji } \\
\text { Sothi-Siswal } \\
\text { Damb Sadaat }\end{array}$ \\
\hline Early-Mature Harappan Transition & 2600-2500 BCE & \\
\hline Mature Harappan & 2500-1900 BCE & $\begin{array}{l}\text { Sindhi Harappan } \\
\text { Kulli Harappan } \\
\text { Sorath Harappan } \\
\text { Punjabi Harappan } \\
\text { Eastern Harappan } \\
\text { Quetta } \\
\text { Late Kot Diji }\end{array}$ \\
\hline Late Harappan & 1900-1300 BCE & $\begin{array}{l}\text { Jhukar (1900-1700 BCE) } \\
\text { Early Pirak (1800-1700 BCE) } \\
\text { Late Sorath Harappan (1900-1600 BCE) } \\
\text { Lustrous Red Ware (1600-1300 BCE) } \\
\text { Cemetary H (1900-1500 BCE) } \\
\text { Swat Valley Period IV (1650-1300 BCE) } \\
\text { Late Harappan in Haryana and Western } \\
\text { Uttar Pradesh (1900-1300 BCE) }\end{array}$ \\
\hline $\begin{array}{l}\text { Painted Grey Ware (PGW) } \\
\text { (north-east regional development) }\end{array}$ & $1300-500 \mathrm{BCE}$ & $\begin{array}{l}\text { Late Harappan-PGW overlap (1300-1000 BCE) } \\
\text { PGW (1100-500 BCE) }\end{array}$ \\
\hline
\end{tabular}

observed in several new archaeobotanical datasets from the north-east zone of the Indus Civilisation, however (Bates 2016; Bates et al. 2017a, 2017b; Petrie and Bates in press; Petrie et al. 2016, 2017). Analysis of floated samples from five of the six small village sites excavated by the Land, Water and Settlement project (Singh et al. 2008, 2010a, 2010b, 2011, 2012, 2013a, 2013b; Petrie et al. 2009, 2016, 2017; Pawar 2012; Bates 2016; Bates et al. 2017a, 2017b; Parikh and Petrie 2017) that are spread across the plains of north-west India has suggested that despite there being some similarities (such as the range of taxa cultivated), there were differences in the proportions of individual crops at each settlement and in each period (Bates 2016; Bates et al. 2017a, 2017b; Petrie et al. 2016, 2017). One element that was common at these settlements across time and space was the preponderance of small hulled native millets (Echinochloa cf. colona, Setaria cf. pumila, and Panicum sp.), which appeared more regularly and often in a greater frequency and proportion than other cereals (Bates 2016; Petrie et al. 2016). These millets were likely to have been grown under mixed intercropping conditions when found together (Petrie and Bates, in press). In the process of exploring these data, we began to question the role these crops might have played in the lives, and especially the diets, of the people actually growing and eating them, particularly their 'relative importance' to one another in practical nutritional terms. This paper develops these questions further, outlining a new, experimental quantification technique that can be employed to consider how different crops were perceived or utilised by people in the past. It also considers what impact this new approach might have on the interpretations that can be drawn from archaeobotanical datasets.

\section{Quantifying archaeobotanical datasets}

There has been much debate about the way that archaeobotanical datasets should be analysed and interpreted (e.g. Hastorf and Popper 1988), and no standard method is applied in all studies. Instead, a range of methods is applied, with the selection being based on the questions being asked and the nature of the remains (Pearsall 1989; Popper 1988). These methods fall into two broad categories: qualitative and quantitative (Pearsall 1989). Qualitative analysis typically presents presence/absence information and explores the data without reference to numbers and has been the most common form of data presentation in Indus archaeobotany (Fuller and Madella 2002; Fuller 2002; Bates forthcoming). While such analysis can be used to address questions such as when a taxon was first introduced at a site or which species co-occur in contexts, it cannot be used to infer the relative importance of individual species (Pearsall 1989). In contrast, quantitative analysis involves methods that explore standardised data (Weber 1999; Pearsall 1989) and can make use of multivariate 
Fig. 1 Map showing excavated sites belonging to the Indus Civilisation and Painted Grey Ware periods, based on published data as of date of paper submission. Data obtained from Indian archaeology, a Review and Possehl (1999). For more analysis, see Bates (forthcoming)

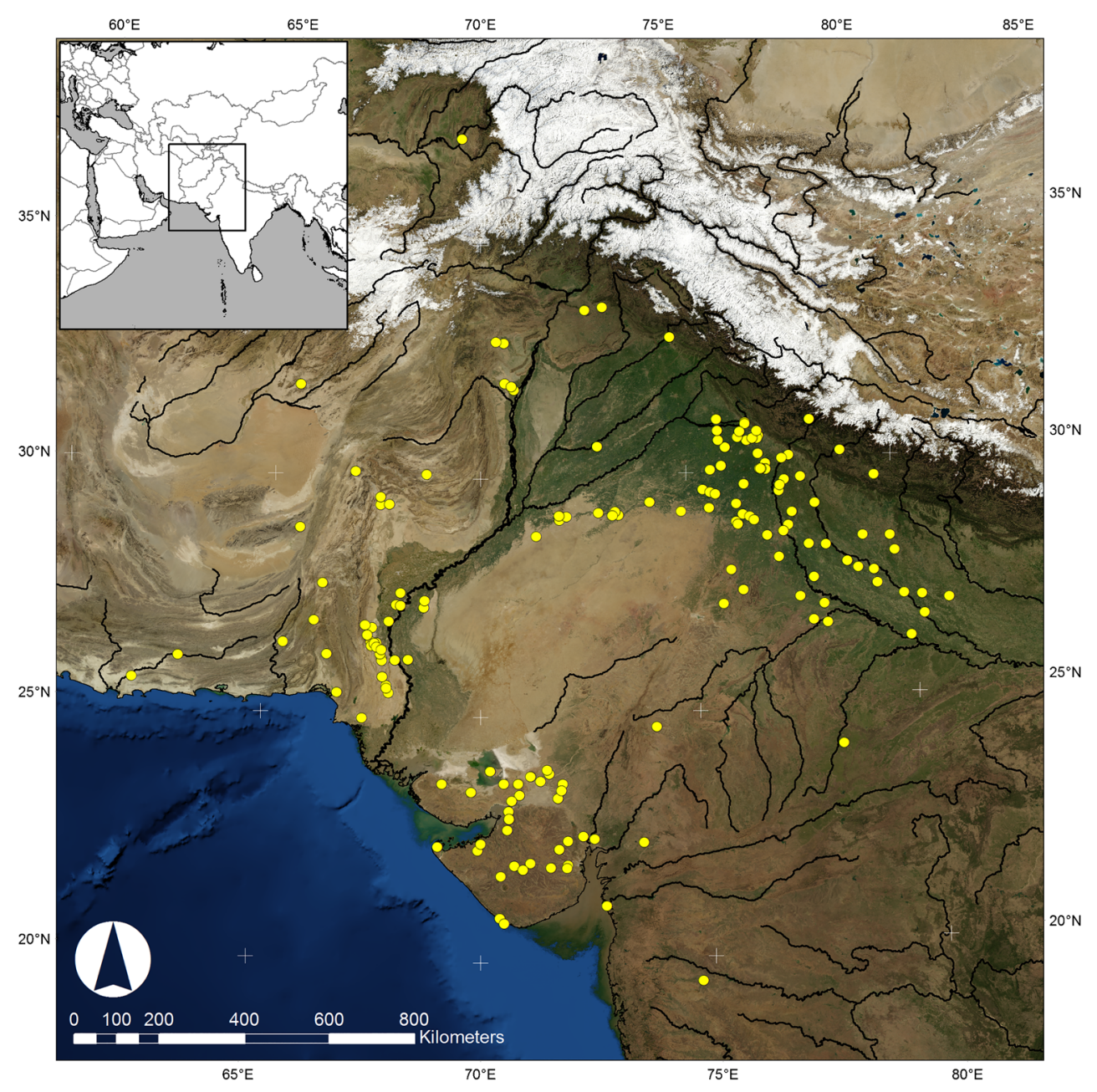

and non-multivariate statistical approaches. This paper will focus on non-multivariate methods, as they are the more commonly used both in general and more specifically in Indus archaeology.

Within Indus archaeobotany, the most frequently used set of non-multivariate statistical analyses are measures of density, ubiquity and proportion (e.g. Weber 1989, 2003; Willcox 1991, 1992; Reddy 1994, 1997, 2003). All three approaches aim to standardise archaeobotanical data sets to make comparisons possible, as they often originate from different context types and from samples of different sizes (Miller 1988). Density is expressed as a ratio of the number of seeds per a specific quantity of sediment (Weber 1999, 2003; Pearsall 1989; Miller 1988). Weber (2003) has argued that density is useful for looking at depositional variability. Ubiquity is the percentage of samples in which a taxon was found and acts as a measure of the frequency of accidental charring events that resulted in the assemblage (Minnis 1981; Weber 1992). Minnis (1981) has suggested that as the number of accidental charring events can be viewed as a reflection of the frequency of utilisation, and ubiquity can therefore be used to show relative changes in use of taxa over time. It is not, however, a reflection of the relative importance of taxa, as a taxon of which only a single seed was found in all contexts would have the same score as a taxon that was found in all contexts in much larger quantities (Popper 1988). Proportion is typically expressed in terms of percentages that look at the relative abundance of each taxa in an assemblage compared with the other taxa present (Weber 1999, 2003; Miller 1988) and can thus be used to gauge floral importance (Weber 1992, 2003; Miller 1988). Miller (1988) has added a caveat that percentages are only meaningful when comparing functionally equivalent elements, so for example including both chaff and seeds in the same percentage analysis would not be appropriate. Fuller (2000; also Fuller and Harvey 2006) has suggested that comparison between groups of crops such as cereals and pulses is also problematic because of differential deposition processes and taphonomy. Despite these issues, proportion remains a common method for looking at the relative importance of individual floral taxa. Combining all three of these analytical methods makes it possible to look at commonality of use (ubiquity), intensity of use (density) and relative importance of taxa (proportion). The datasets explored in this paper have previously been analysed using these three 
statistical approaches (Bates 2016) and will be referred to throughout this paper.

Within the zone occupied by Indus Civilisation populations, there was a wide range of different crops that were known and used, therefore, the issue of relative importance of a crop within an individual assemblage becomes more critical and informative. The Indus Civilisation has been described as a melting pot of botanical influences (Bates 2016). Crop types range from the commonly cited rabi (winter) package of Near Eastern cereals and pulses, to kharif (summer) crops including the African millets, whose date of arrival in the Indus has been debated (e.g. Weber 1998; Weber and Fuller 2008; Weber and Kashyap 2016), to native millets and pulses from the south and east of the subcontinent that have been dismissed or disregarded in some discussions (e.g. Fuller and Harvey 2006; Weber and Fuller 2008; Bates 2016; Weber and Kashyap 2016; Petrie et al. 2016) and the much debated issue of the adoption and use of rice (see Fuller 2006; Fuller et al. 2010; Madella 2014; Bates et al. 2017a; Petrie et al. 2016; see Petrie and Bates in press). Here, we will focus on cereals, as they are the most commonly reported botanical remains from Indus sites (Fuller and Madella 2002; Bates 2016, forthcoming). Cereals were also the most dense, the most ubiquitous and proportionately the largest plant group from the quantified sites that have been explored (Bates 2016; Bates et al. 2017a, 2017b; Petrie and Bates in press; Petrie et al. 2016, 2017). Even when focusing just on the cereals, there are difficulties in making comparisons, as each species has different rates of production. For example, the smaller grained millet Echinochloa sp. can produce up to 6000 grains per plant, while larger grained wheat (Triticum sp.), averages 100-300 grains per plant. This variance means that comparing species directly in terms of raw numbers is potentially problematic as to do so assumes direct similarity and therefore comparability between species.

Given this limitation, and given that it is important to actually understand how humans used these plants as food, we suggest that an alternative approach for interpretation is required. For example, it is typically argued that charred remains are likely to reflect the daily routine actions of the final stages of crop processing towards food preparation before consumption and therefore some degree of human meal choice and daily activity on site, rather than acting as a direct reflection of what was growing in the fields (Stevens 2003; Fuller et al. 2014). One of the key elements of diet is calories, and as we will show, in the case of the wide range of cereals available to Indus populations, the quantity of calories provided by each taxa varies greatly. This variability suggests that looking at the proportion of calories provided by different cereals has the potential to indicate their relative importance to the daily lives of the people using them, thereby grounding the idea of 'importance' in the actions and choices of the people of the past. Calories have often been used as a standard metric in other fields such as optimal foraging theory, where they are used to explore how and why food items have been incorporated into diets (see Hill 1988; Winterhalder and Goland 1997; Borgerhoff Mulder and Schacht 2012). Of course, the importance of a crop goes beyond simply calorific content, and other factors influence whether a farmer chooses to use individual crops, such as ecological tolerances (e.g. Petrie and Bates in press; Petrie et al. 2017), investment of time and labour (e.g. Brookfield 1986; Morrison 1994; Bates et al. 2017a, 2017b; Petrie and Bates in press; Bates in prep) and their role in the economy (e.g. Brookfield 1986; Morrison 1994; Bates in prep). It should also be noted that calorific content is not the only aspect of nutrition that might affect a decision to incorporate a crop into a diet, macronutrients such as carbohydrates, lipids, proteins and mineral content will also affect decisions, and it will be important to undertake further work into these aspects in the future. Similarly, cultural and social choices affect decisions about food (Appadurai 1981; Goody 1982; Fischler 1988; Gumerman IV 1997; Lyons and D'Andrea 2003; Smith 2006; Twiss 2012; Fuller and Rowlands 2011; Hastorf 2016). As Sherratt (1991: 50) has pointed out: "we do not eat species, we eat meals", we eat food. Food is made up of a series of categories of what is good to eat and what is not good to eat (Levi Strauss 1968: $\mathrm{xx}$ ), and by categorising food in such a way it intersects with aspects of social identity, allowing for it to become embedded in expressions of self, such as ethnicity, gender, age, status, ideology/religion (Appadurai 1981; Goody 1982; Fischler 1988; Gumerman IV 1997; Smith 2006; Twiss 2012; Hastorf 2016). Culturally informed choices about taste and texture will also affect cooking technologies and thus the choices of crops used, for example a desire for bread might affect decisions about grinding and thus also grain choices based on starch, protein and gluten content, or the cultural liking for noodles and stewed/boiled foods might lead to a focus on 'sticky' cereals with high waxy starch content (Lyons and D'Andrea 2003; Fuller and Rowlands 2011). Nonetheless, we argue here that calories are a simple metric that have the potential to begin to break down the way traditional quantification methods have been applied to look more at how people thought about their crops from the view of the farmers and the people eating the food produced.

It is important to note, as with all statistical approaches within archaeobotany, that many factors need to be taken into consideration when quantifying the data, and as such, approaching cereal use from the point of view of calorie proportion is a rough estimate of relative nutritional importance rather to provide an exact reflection of the calorie count within the diets of the past. As in all statistical methods, this approach assumes that differential preservation by charring is negligible, a point that needs to be taken into consideration in interpreting the data. Taphonomy varies depending on the 
grain size, with larger grains often being more damaged due to water and starch alternations in cooking, while smaller grains like millets are more likely to be lost during cooking. Millets and rice are also commonly boiled not ground, and this could increase their survival over wheat and barley. Grain processing and storage differences also have the potential to alter ubiquity and abundances of grain, and differences in the role of grains in an economy (e.g. for food and foddering) have the potential to affect their likelihood of preservation. We have previously explored differences in processing (Bates et al. $2017 \mathrm{~b}$ ) and have outlined the different pathways through cleaning at each site for the different grains. Foddering by feeding grains to cattle (in the form of dung fuel containing grain fragments) is also a possibility.

Calorific quantification is not being proposed here as an approach to replace other methods of quantification in the analysis of macrobotanical remains, nor to provide a direct reflection of the exact calorific content of a single meal from the past, but rather to provide another way of thinking about relative importance, in terms of significance to diet rather than in abstracted numbers. The calculations used to estimate the calories in $100 \mathrm{~g}$ of grain per species are shown in Table 2, with the data being taken from modern studies. The calories per $100 \mathrm{~g}$ of grain were then divided by the number of grains per $100 \mathrm{~g}$ (Table 2) to create a figure for the number of calories per grain (Table 2). We recognise that grain size may be a factor in calculations of calories per grain, and suggest that future studies should be carried out to look at calories per grain both in terms of intra-species differences and also chronologically, to ascertain whether the differences seen between taxa are greater than those within species (see Table 2). There is some likelihood that there were changes in grain size over time and within species, particularly in response to changing practice by farmers and the potential impact of climatic and ecological variability. Further research looking into this process, specifically in relation to wheat and barley, and also to address the issue of sheer mass of carbohydrates, is ongoing

Table 2 Calculations used to create calories per grain. These were then used to create a proportion of the cereal calories. Sources: Calories per 100 g: USDA (2014); grains per 100 g Hordeum vulgare: Penn. State (2014); Triticum aestivum: Ali et al. (2008); Oryza sp.: FAO (2014); Echinochloa colona: Sparacino et al. (2002); Setaria pumila: Steel et al. (1983)

\begin{tabular}{llll}
\hline Species & $\begin{array}{l}\text { Calories } \\
\text { (kcal) } \\
\text { per } 100 \mathrm{~g}\end{array}$ & $\begin{array}{l}\text { Grains } \\
\text { per } 100 \mathrm{~g}\end{array}$ & $\begin{array}{l}\text { Calories per grain } \\
\text { (kcal/100 g divided } \\
\text { by grains/100 g) }\end{array}$ \\
\hline Hordeum vulgare & 354 & 2998 & 0.118 \\
Triticum aestivum & 361 & 3096 & 0.117 \\
Oryza sp. & 358 & 4000 & 0.09 \\
Echinochloa colona & 300 & 75,758 & 0.004 \\
Setaria pumila & 336 & 90,909 & 0.004 \\
\hline
\end{tabular}

(see Bates et al. in prep.). In the absence of relevant ancient datasets, modern studies have been used to provide a first approximation in demonstrating the value of calorific quantification studies, which can be used alongside other quantification methods to look at the role of different grains within archaeological farming diets.

Panicum spp. is a broad group of millets that includes several species that are often difficult to identify given the condition of the charred grains being analysed. The available references suggest that Panicum sp. is similar in calorific value range and grain production to Echinochloa colona and Setaria pumila. As Panicum sp. formed only a small proportion of any of the samples presented here, an assumption was made that it provided $0.004 \mathrm{kcal}$ per grain like the other millets. This was also assumed for the small hulled millets with long embryos of the genera Setaria sp., Echinochloa sp. and Brachiaria sp. (the SEB group) and small indeterminate millets, as these were likely to be Echinochloa sp. and Setaria sp. given that the majority of identifications were of these millets.

The average density of seeds per period was used to work out the calorie proportions: (density of grain $\times$ calories per grain)/total calories of all cereals at site in time period $\times 100$.

\section{The sites and samples}

The samples discussed here were recovered from settlement sites excavated by the Land, Water, Settlement project (Fig. 2; see Petrie et al. 2017). Charred macrobotanical remains were recovered from five sites using bucket flotation and a 500- $\mu \mathrm{m}$ mesh. These sites will be discussed broadly from west to east. The raw data counts can be found in the Supplementary Information.

\section{Dabli vas Chugta}

Dabli vas Chugta is the western-most of the five sites, and the extant Mature Harappan levels were excavated and sampled (Singh et al. 2012). This 5-6-ha site lies $7 \mathrm{~km}$ north-east of Kalibangan, an important small urban centre. A total of 37 flotation samples from the site were analysed (Bates 2016; Bates et al. 2017a, 2017b; Petrie and Bates in press; Petrie et al. 2016, 2017; see Supplementary Information).

As outlined in Table 3, Hordeum vulgare (barley) was the most ubiquitous, dense and highest proportioned of the cereals found at Dabli vas Chugta. However, there was also a high proportion of millets (all species) present with similarly high ubiquity. Due to preservation issues, the majority of the millet grains were either identifiable as smallgrained hulled millets or could be attributed to the SEB group category. The next highest proportioned cereal was Hordeum/Triticum, which was made up of large grains that could not be identified beyond a generalised barley/wheat 
Fig. 2 Land, Water, Settlement sites explored in this study (shown in white) and other important sites in study region (shown in black). Circle size indicates site size hierarchy

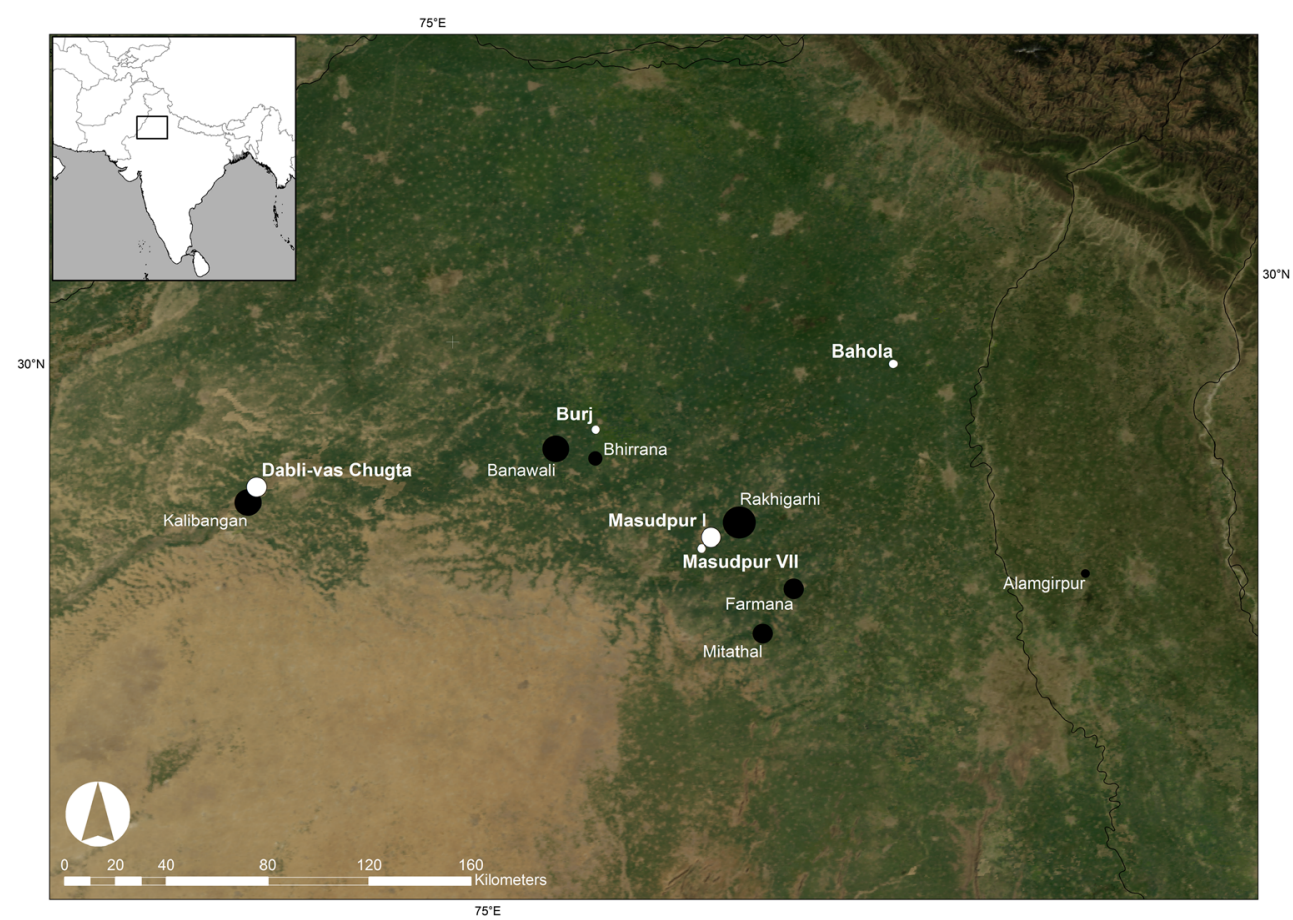

level. These types were found in similar ubiquity to the millets, but in lower density. This pattern suggested that barley and a range of millets were important cereals at the site, as they were used in similar frequency, intensity and proportion (Table 3).

When the cereal caloric proportions are considered (Fig. 3), however, the dominance of barley is more pronounced. This is because even though barley produces fewer grains per plant than the millets, the grains are richer in calories. Therefore, although barley and millets have a similar ubiquity, barley is likely to have provided the main proportion of the calories in the Mature Harappan period at Dabli vas Chugta, whereas

Table 3 Ubiquity, density and proportion of cereals at Dabli vas Chugta (Bates 2016)

\begin{tabular}{llll}
\hline Cereal & $\begin{array}{l}\text { Ubiquity } \\
(\% \text { contexts })\end{array}$ & $\begin{array}{l}\text { Density } \\
\text { (per 10 l) }\end{array}$ & $\begin{array}{l}\text { Proportion } \\
(\% \text { of cereals })\end{array}$ \\
\hline Hordeum vulgare & 31.58 & 0.59 & 45.28 \\
Triticum sp. & 2.63 & 0.01 & 1.03 \\
Hordeum/Triticum & 21.05 & 0.27 & 20.75 \\
Total Hordeum, Triticum & 40.54 & 0.87 & 67.06 \\
$\quad$ and Hordeum/Triticum & & & \\
Setaria sp. & 2.63 & 0.01 & 1.03 \\
Panicum sp. & 2.63 & 0.01 & 1.03 \\
SEB & 13.16 & 0.07 & 5.15 \\
Indet. small millet & 7.89 & 0.34 & 25.73 \\
Total millet & 23.68 & 0.43 & 32.94 \\
\hline
\end{tabular}

millets and wheat played a lesser role in dietary calorie acquisition.

It could be argued from this evidence that the rabi (winter) cereal barley was the most important, frequently and intensively used element of the plant food diet at Dabli vas Chugta, and that the kharif (summer) millets were used as a supplement, perhaps not simply in terms of calories but also in terms of other aspects including bulking up a meal, for year-round food security or for specific culinary uses.

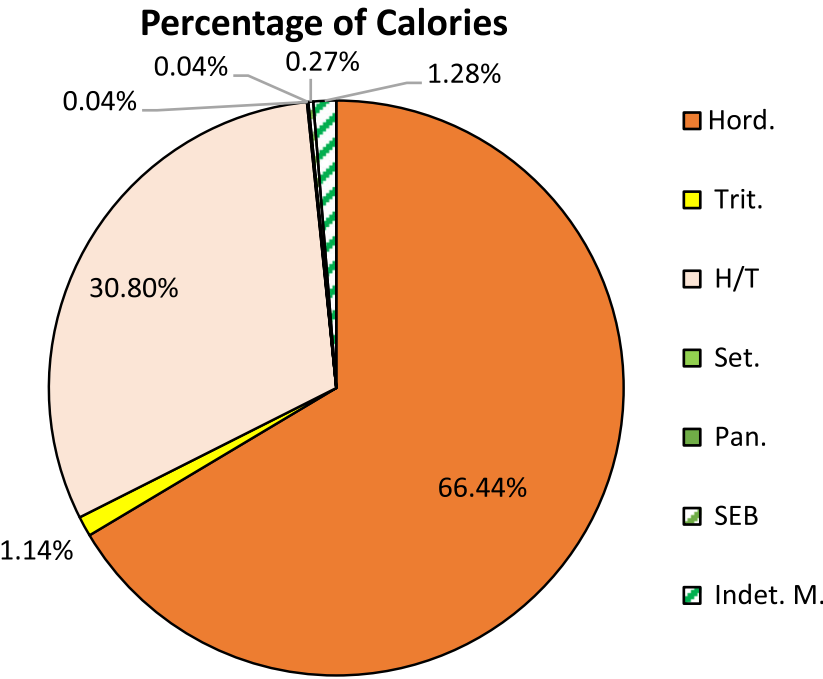

Fig. 3 Proportion of cereal calories by species/genera at Dabli vas Chugta (Bates 2016) 


\section{Burj}

The site of Burj is located in Fatehabad District and was occupied during the Early Harappan and PGW periods (Singh et al. 2010a). It is close to Kunal, which has an unusually rich assemblage of Early, Early-Mature Transition and Mature Harappan material (Khatri and Acharya 1995), and a relatively short distance from both Banawali and Bhiranna. Previous work (Bates 2016; Bates et al. 2017a, 2017b; Petrie and Bates in press; Petrie et al. 2016, 2017) has shown that the Early Harappan samples were poorly preserved and cannot be quantified, but it is noticeable that the only material preserved were large grained cereals, predominantly of wheat/ barley type. The PGW period samples were, however, better preserved, and 14 samples were analysed (Bates 2016; Bates et al. 2017a, 2017b; Petrie and Bates in press; Petrie et al., 2016, 2017; see Supplementary Information).

In contrast to Dabli vas Chugta, the majority of cereals at Burj were small hulled millets (Table 4).

Millets were the cereal type that occurred in the highest density and the most ubiquity at Burj. Of those identifiable to genera or species, Echinochloa cf. colona formed the highest proportion, occurring in the highest density and ubiquity. The second most prevalent millet was Setaria cf. pumila, with Panicum sp. being slightly less ubiquitous and occurring in a lower density. Combined, the small millets were the most ubiquitous, had the highest density and were proportionately the largest group of cereals. However, Hordeum vulgare (barley) was also found in over half of all samples, though in a much lower density and proportion than the millets. In contrast, Triticum sp. (wheat) was not ubiquitous, nor was it found in great proportions, forming less than $1 \%$ of the entire cereal assemblage. These data suggest that in the PGW period, millets were the dominant crop, with barley being used with some frequency, but with less intensity, while wheat was neither a major nor a regular component of the diet at Burj.

Table 4 Ubiquity, density and proportion of cereals at Burj in the PGW period (Bates 2016)

\begin{tabular}{llll}
\hline Cereal & $\begin{array}{l}\text { Ubiquity } \\
(\% \text { contexts) }\end{array}$ & $\begin{array}{l}\text { Density } \\
\text { (per 10 1) }\end{array}$ & $\begin{array}{l}\text { Proportion } \\
(\% \text { of cereals) }\end{array}$ \\
\hline Hordeum vulgare & 57.14 & 0.82 & 6.01 \\
Triticum sp. & 7.14 & 0.04 & 0.26 \\
Hordeum/Triticum & 57.14 & 0.50 & 3.66 \\
Total Hordeum, Triticum & 64.28 & 1.36 & 9.93 \\
$\quad$ and Hordeum/Triticum & & & \\
Echinochloa sp. & 57.14 & 6.46 & 47.26 \\
Setaria sp. & 42.86 & 3.50 & 25.59 \\
Panicum sp. & 21.43 & 0.46 & 3.39 \\
SEB & 21.43 & 0.86 & 6.27 \\
Indet. small millet & 35.71 & 1.04 & 7.57 \\
Total millets & 78.57 & 12.32 & 90.07 \\
\hline
\end{tabular}

When these data are converted to proportions of calories, however, this pattern changes (Fig. 4). Instead of millets being the dominant group, the major role of barley and Hordeum/ Triticum is emphasised, and millets are shown to have formed only a quarter of the calorific input into the assemblage. Thus, although the millets were the dominant crop in terms of ubiquity, density and proportions, they provided a lower proportion of the calorific input than barley.

Kharif cereals were therefore the most regularly and intensely used cereal group, but not necessarily the most important in terms of calorific input and the less frequently and less intensely used rabi cereals may have been the calorific staples.

\section{Masudpur VII}

Masudpur VII is one of the several small village sites located around the modern village of the same name and lies about $15 \mathrm{~km}$ from the Indus urban centre of Rakhigarhi (Petrie et al. 2009, 2016; Singh et al. 2010b). This settlement had evidence for occupation in the Early, Mature and Late Harappan periods, and a total of 25 macrobotanical samples were analysed: 10 Early Harappan, 12 Mature Harappan and 3 Late Harappan (Bates 2016; Bates et al. 2017a, 2017b; Petrie and Bates in press; Petrie et al. 2016, 2017; see Supplementary Information).

In the Early Harappan deposits at Masudpur VII (Table 5), millets were the most ubiquitous of the cereals, specifically, Echinochloa sp. (mostly Echinochloa colona) as well as being the most densely occurring and proportionately the largest group of cereals. Setaria sp. (mostly Setaria pumila) was also found frequently in large proportions. Some Panicum sp. was also identified. Hordeum vulgare (barley) was found in high densities and in similar proportions to Echinochloa sp., but

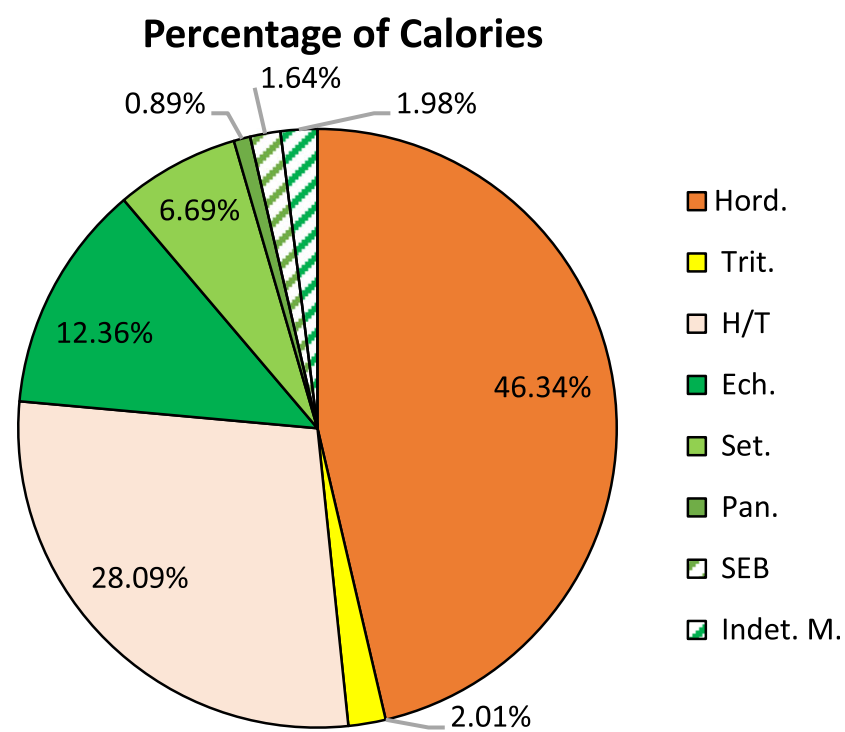

Fig. 4 Proportion of cereal calories by species/genera at Burj in the PGW (Bates 2016) 
Table 5 Ubiquity, density and proportion of cereals at Masudpur VII in the Early Harappan period (Bates 2016)

\begin{tabular}{llll}
\hline Cereal & $\begin{array}{l}\text { Ubiquity } \\
(\% \text { contexts })\end{array}$ & $\begin{array}{l}\text { Density } \\
\text { (per 10 1) }\end{array}$ & $\begin{array}{l}\text { Proportion } \\
\text { (\% of cereals) }\end{array}$ \\
\hline Hordeum vulgare & 40 & 1.25 & 24.27 \\
Triticum sp. & 20 & 0.10 & 1.94 \\
Hordeum/Triticum & 20 & 0.35 & 6.80 \\
Total Hordeum, Triticum & 50 & 1.7 & 33.01 \\
$\quad$ and Hordeum/Triticum & & & \\
Oryza sp. & 20 & 0.10 & 1.94 \\
Echinochloa sp. & 70 & 1.45 & 28.16 \\
Setaria sp. & 40 & 0.55 & 10.68 \\
Panicum sp. & 30 & 0.35 & 6.80 \\
SEB & 40 & 0.40 & 7.77 \\
Indet. small millet & 50 & 0.60 & 11.65 \\
Total millets & 80 & 3.35 & 65.06 \\
\hline
\end{tabular}

barley was not as ubiquitous as the millets, being present in only $40 \%$ of contexts. It can therefore be argued that millet was used at the site in the same intensity and proportion as barley, but more frequently. Two other cereals were identified in the Early Harappan period deposits: Triticum cf. aestivum/ durum (bread wheat) and Oryza sp. (rice). These were both found in a lower ubiquity, density and proportion, and it can be suggested that they did not play a large role in the diet at the site in this period. The lower rice, wheat and barley metrics could be explained through taphonomy. Rice is often boiled, which could result in it being incorporated less frequently than other cereals, while barley and wheat are often ground, and the high water and starch content in these grains can also lead to damage to the grains that results in poor preservation potential.

This pattern changed in the Mature Harappan period (Table 6). While millets as a group were still more ubiquitous than other cereals, they were not the largest group in either proportion or density, and instead Hordeum/Triticum, and

Table 6 Ubiquity, density and proportion of cereals at Masudpur VII in the Mature Harappan period (Bates 2016)

\begin{tabular}{llll}
\hline Cereal & $\begin{array}{l}\text { Ubiquity } \\
\text { (\% contexts) }\end{array}$ & $\begin{array}{l}\text { Density } \\
\text { (per 10 l) }\end{array}$ & $\begin{array}{l}\text { Proportion } \\
(\% \text { of cereals) }\end{array}$ \\
\hline Hordeum vulgare & 8.33 & 0.04 & 2.19 \\
Triticum sp. & 8.33 & 0.50 & 27.32 \\
Hordeum/Triticum & 25 & 0.75 & 40.98 \\
Total Hordeum, Triticum & 25 & 1.29 & 70.49 \\
$\quad$ and Hordeum/Triticum & & & \\
Echinochloa sp. & 33.33 & 0.33 & 18.03 \\
SEB & 16.67 & 0.08 & 4.37 \\
Indet. small millet & 8.33 & 0.13 & 7.10 \\
Total millets & 41.67 & 0.54 & 29.51 \\
\hline
\end{tabular}

more specifically Triticum sp. (wheat) was the dominant crop in both of these measures. The millets in the Mature Harappan assemblage were also different from those used in the Early Harappan period: no Setaria sp. or Panicum sp. were identified, and instead only Echinochloa sp. (mostly Echinochloa cf. colona) was noted alongside the SEB group and small millet categories. This suggests that although wheat was not commonly used, when it was, it was used more intensively and formed a larger proportion of the cereal assemblage. Millets were thus used less intensively and in smaller proportions, but more frequently.

In the Late Harappan period, there was again a change at Masudpur VII (Table 7), and it was in some ways a reversion to the pattern seen in the Early Harappan period, though this interpretation has to be tempered by an acknowledgment of the low number of samples. The data suggested that rice had made a return, but it was now found in the same ubiquity as Hordeum/Triticum, and Panicum sp. also reappeared again. However, although rice and Hordeum/Triticum were the most ubiquitous species, again the small hulled millets group was found in a greater density and was proportionally larger. Of the millets, one species dominated: Echinochloa sp., which was found in the same density and proportion as rice. Its density and proportions was slightly lower than Hordeum/ Triticum, but very little genera specific data for this group could be gathered due to preservation: no wheat was noted and only 0.17 grains of barley was noted per 101 sediment. From these data, it therefore seems that Oryza sp. and Hordeum/Triticum were the most commonly identified cereals in the Late Harappan period and used in similar intensity and proportion to Echinochloa sp.

When these data from these three periods of occupation are converted to calories, however, a different picture emerges. Figure 5a shows that in the Early Harappan period, the majority of calories were provided by barley (66\%), while wheat, rice and millets make up similar calorific proportions of between 4 and 6\%. In the Mature Harappan period (Fig. 5b), the

Table 7 Ubiquity, density and proportion of cereals at Masudpur VII in the Late Harappan period (Bates 2016)

\begin{tabular}{llll}
\hline Cereal & $\begin{array}{l}\text { Ubiquity } \\
\text { (\% contexts) }\end{array}$ & $\begin{array}{l}\text { Density } \\
\text { (per 10 1) }\end{array}$ & $\begin{array}{l}\text { Proportion } \\
\text { (\% of cereals) }\end{array}$ \\
\hline Hordeum vulgare & 33.33 & 0.17 & 2.70 \\
Hordeum/Triticum & 66.67 & 1.50 & 24.32 \\
$\begin{array}{c}\text { Total Hordeum, Triticum, } \\
\quad \text { and Hordeum/Triticum }\end{array}$ & 100 & 1.67 & 27.02 \\
Oryza sp. & 66.67 & 1.17 & 18.92 \\
Echinochloa sp. & 33.33 & 1.17 & 18.92 \\
Panicum sp. & 33.33 & 0.17 & 2.70 \\
Indet. small millet & 33.33 & 2.00 & 32.43 \\
Total millets & 33.33 & 3.34 & 54.05 \\
\hline
\end{tabular}


a Percentage of Calories (Early Harappan)

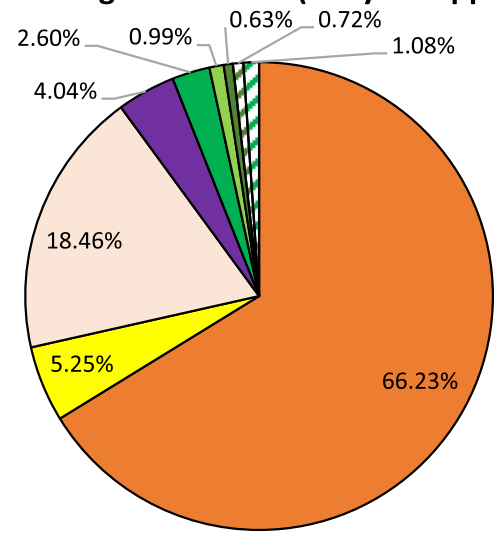

b Percentage of Calories (Mature Harappan)

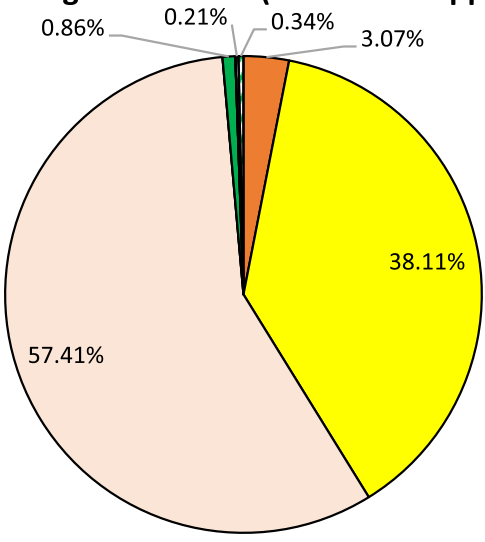

口Hord.

$\square$ Trit.

$\square \mathrm{H} / \mathrm{T}$

$\square$ Ech.

SEB

$\square$ Indet M.

C Percentage of Calories (Late Harappan)

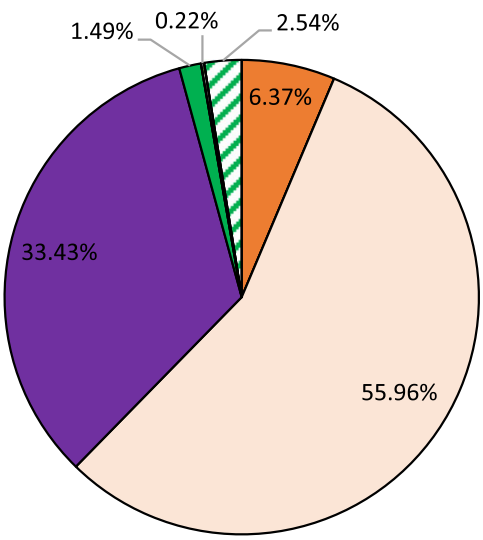

口Hord.

$\square$ Trit.

$\square \mathrm{H} / \mathrm{T}$

口 Oryza

口 Ech.

๑ Pan.

Indet. M.

Fig. 5 Proportion of cereal calories by species/genera at Masudpur VII in the a Early, b Mature and c Late Harappan periods (Bates 2016)

role of wheat increased, while millets made up only $1 \%$ of the calories. The majority of calorific input was provided by the generalised category of Hordeum/Triticum, but looking at the identifiable grains, wheat was proportionately larger in calorie provision than barley. In the Late Harappan period (Fig. 5c), there is a more mixed picture, with Hordeum/Triticum forming around half of the calories, rice providing a further
$33 \%$, and barley and millet each providing a relatively small proportion of calories.

The data from Masudpur VII thus varies considerably by period in both traditional quantification methods and calculations of calories. While the small hulled millets were ubiquitous in all periods, their density and proportionate role varied by period, and calorifically, they did not form a significant part of the assemblage in any period. It is notable that species with larger grains, although less ubiquitous, played a more significant role in calorie provision. These species varied, however, between periods, mirroring perhaps the role of larger grains in the traditional proportions: with barley being dominant in the Early Harappan, wheat in the Mature Harappan, and Hordeum/Triticum and rice in the Late Harappan.

\section{Masudpur I}

Masudpur I was another of the village sites in the hinterland of Rakhigarhi, slightly to the north-east of Masudpur VII (Petrie et al. 2009; Singh et al. 2010b). This site had only Mature Harappan period remains, and 29 samples were analysed (Bates 2016; Bates et al. 2017a, 2017b; Petrie and Bates in press; Petrie et al. 2016, 2017; see Supplementary Information).

Hordeum vulgare (barley), small-grained hulled millets Echinochloa cf. colona, Setaria cf. pumila, Panicum sp., and the large grained Hordeum/Triticum, Triticum aestivum/ durum (bread wheat) and Oryza sp. (rice) were all present (Table 8, Bates 2016). Of these, the small hulled millets were the most ubiquitous group and occurred in the highest density, forming the largest proportion of the cereals (and indeed all crops). Barley and rice, however, were only marginally less ubiquitous than millets but were found in similar densities and proportions to the millets. These proportions suggest that although slightly less common, barley and rice were as

Table 8 Ubiquity, density and proportion of cereals at Masudpur I (Bates 2016)

\begin{tabular}{llll}
\hline Cereal & $\begin{array}{l}\text { Ubiquity } \\
(\% \text { contexts) }\end{array}$ & $\begin{array}{l}\text { Density } \\
\text { (per 10 1) }\end{array}$ & $\begin{array}{l}\text { Proportion } \\
\text { (\% of cereals) }\end{array}$ \\
\hline Hordeum vulgare & 62.07 & 8.64 & 19.90 \\
Triticum sp. & 37.93 & 0.80 & 1.85 \\
Hordeum/Triticum & 72.41 & 4.18 & 9.63 \\
Total Hordeum, Triticum & 86.21 & 13.62 & 31.37 \\
$\quad$ and Hordeum/Triticum & & & \\
Oryza sp. & 55.17 & 9.41 & 21.67 \\
Echinochloa sp. & 86.21 & 5.62 & 12.94 \\
Setaria sp. & 72.41 & 7.53 & 17.35 \\
Panicum sp. & 55.17 & 1.70 & 3.91 \\
SEB & 65.52 & 1.76 & 4.06 \\
Indet. small millet & 62.07 & 3.78 & 8.71 \\
Total millets & 89.66 & 20.39 & 46.96 \\
\hline
\end{tabular}


intensively used and as important to diet in relative terms. Wheat was also present, but as at Burj and Dabli vas Chugta, it was only present in a small number of contexts, in low density and formed less than $2 \%$ of the cereal assemblage.

As at the other sites when these data from Masudpur I are converted to proportion of calories (Fig. 6), the calorific role of millets was low, in this instance to less than $3 \%$ of the assemblage. The major calorific input is evenly distributed between rice and barley, and wheat makes only a small proportionate contribution, similar to the millets. These data suggests that, although they were not used quite as regularly as millets, barley and rice were perhaps the most important crops at Masudpur I in terms of intensity and proportion of use, and also in calorific terms.

\section{Bahola}

The final site discussed here, Bahola, provides yet another perspective on rural Indus agriculture in north-west India. Bahola is the most easterly of the sites discussed here and had evidence for Late Harappan and PGW occupation as well as Early Historic levels (Singh et al. 2013a). In total, 20 Late Harappan and 10 PGW samples were analysed.

In the Late Harappan period, small hulled millets dominated in terms of ubiquity, density and proportion statistics (Bates 2016; Bates et al. 2017a, 2017b; Petrie and Bates in press; Petrie et al. 2016, 2017). Oryza sp. (rice) and Hordeum/ Triticum were also present in high ubiquities (only slightly less than the small hulled millets), while barley was low in ubiquity and wheat was not attested (Table 9). This pattern continued in the densities and proportions: with millets, especially Echinochloa sp. (mostly Echinochloa cf. colona), being the largest and most dense group, closely followed by rice which had similar proportions to Setaria sp. (most Setaria

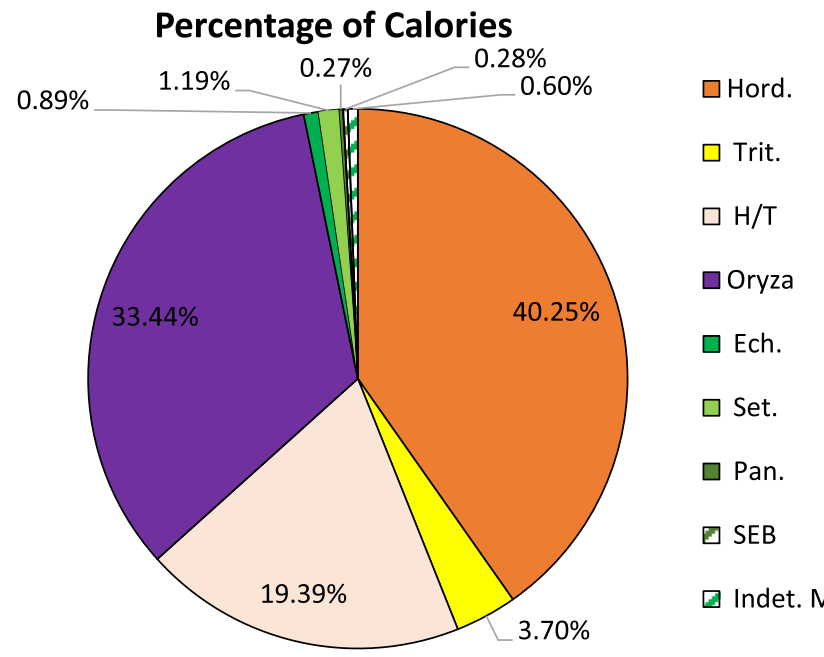

Fig. 6 Proportion of cereal calories by species/genera at Masudpur I (Bates 2016)
Table 9 Ubiquity, density and proportion of cereals at Bahola in the Late Harappan period (Bates 2016)

\begin{tabular}{llll}
\hline Cereal & $\begin{array}{l}\text { Ubiquity } \\
\text { (\% contexts) }\end{array}$ & $\begin{array}{l}\text { Density } \\
\text { (per 10 1) }\end{array}$ & $\begin{array}{l}\text { Proportion } \\
\text { (\% of cereals) }\end{array}$ \\
\hline Hordeum vulgare & 20 & 0.10 & 0.80 \\
Hordeum/Triticum & 60 & 0.94 & 7.32 \\
Total Hordeum, Triticum & 60 & 1.04 & 8.12 \\
$\quad$ and Hordeum/Triticum & & & \\
Oryza sp. & 60 & 2.64 & 20.49 \\
Echinochloa sp. & 75 & 3.92 & 30.50 \\
Setaria sp. & 55 & 2.25 & 17.52 \\
Panicum sp. & 25 & 0.29 & 0.81 \\
SEB & 40 & 0.10 & 2.22 \\
Indet. small millet & 70 & 2.61 & 20.32 \\
Total millet & 75 & 9.18 & 71.37 \\
\hline
\end{tabular}

cf. pumila), Hordeum/Triticum which had slightly lower proportions, and Hordeum vulgare (barley), which comprised only a small proportion of the assemblage.

A similar pattern was seen in the PGW period samples at Bahola (Table 10): millets were the most dominant group in terms of ubiquity, density and proportion, closely followed by rice and Hordeum/Triticum, with barley being rarely found. Additionally, Triticum sp. (wheat) was found in the PGW levels but in low ubiquity, density and proportion.

Again, this pattern is different when looking at the proportion of calories (Fig. 7). In the Late Harappan period, rice makes up the largest calorific proportion, followed by Hordeum/Triticum, whereas millets make up less than $10 \%$ of the calories, and barley is the smallest proportion. In the PGW period, the roles of rice and Hordeum/Triticum reverse, and the calorific proportion of barley increases so that it is

Table 10 Ubiquity, density and proportion of cereals at Bahola in the PGW period (Bates 2016)

\begin{tabular}{llll}
\hline Cereal & $\begin{array}{l}\text { Ubiquity } \\
(\% \text { contexts) }\end{array}$ & $\begin{array}{l}\text { Density } \\
\text { (per 10 1) }\end{array}$ & $\begin{array}{l}\text { Proportion } \\
\text { (\% of cereals) }\end{array}$ \\
\hline Hordeum vulgare & 20 & 0.10 & 3.05 \\
Triticum sp. & 10 & 0.05 & 1.52 \\
Hordeum/Triticum & 50 & 0.42 & 12.80 \\
Total Hordeum, Triticum & 60 & 0.57 & 17.38 \\
$\quad$ and Hordeum/Triticum & & & \\
Oryza sp. & 60 & 0.36 & 10.98 \\
Echinochloa sp. & 70 & 0.64 & 19.51 \\
Setaria sp. & 60 & 0.37 & 11.28 \\
Panicum sp. & 30 & 0.18 & 5.49 \\
SEB & 20 & 0.17 & 5.18 \\
Indet. small millet & 70 & 0.99 & 30.18 \\
Total millet & 80 & 2.53 & 71.65 \\
\hline
\end{tabular}



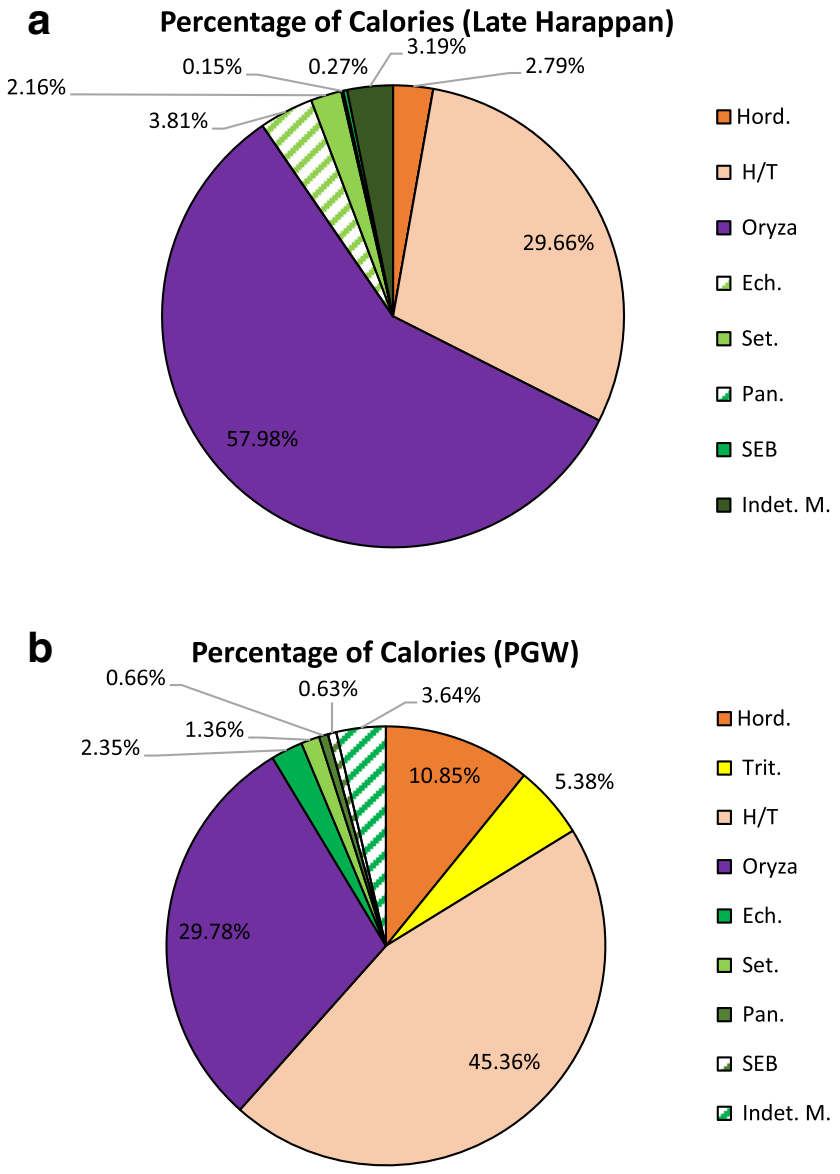

Fig. 7 Proportion of cereal calories by species/genera at Bahola in the a Late Harappan and b PGW periods (Bates 2016)

greater than that of the millets, but it is still less than $10 \%$. Wheat forms only a small proportion of calorific input.

\section{Discussion}

The data outlined here suggests that millets formed a large proportion of the assemblage at all sites, and as a group, millets were the most frequently utilised crop. However, when the statistics for millets are converted into proportions of calories, it is evident that even in the assemblages where they were particularly abundant and ubiquitous, these small-grained hulled millets formed only a small proportion of the calorific input into the diet (Fig. 8). The only site at which they could be argued to have provided a significant proportion of the calories was Burj in the PGW period, where they formed onequarter of the cereal-based calories. As such, it could be argued that millets did not play as 'important' as calorific role in the diet of Indus populations in north-west India when compared with other crops.

This observation has to be tempered by the fact that although lower in calories, millets were included more regularly in each of the assemblages. This regularity of appearance potentially indicates that calorific value was not necessarily the main concern in cereal use and that other aspects such as taste, functionality (i.e. what millet could be used to make), adaptation to arid conditions and/or cropping strategies were equally or perhaps even more important.

This observation does not, however, take into account differential preservation which may have played a significant role in the formation of these assemblages. These include aspects such as the different grains not all being processed and cooked in the same way and thus not necessarily having the same chances of being charred and included in the soil assemblage, differential destruction during burning of smaller elements like millets, the potential destruction of larger grains such as the wheat and barley from food preparation (grinding) or during cooking (water and starch changes causing a porous and thus more fragile appearance). These processes may have changed the contents the assemblages and therefore the proportion of seeds in the assemblage, thus, changing calorie ratios. We thus reiterate that this approach provides a first approximation but nonetheless also indicates some interesting avenues for future work for assessing food choice beyond the use of standard quantification of archaeobotanical datasets.

The Indus Civilisation extended across an area that had highly variable rainfall, riverine conditions, vegetation and temperatures, and as such, it is impossible to simply characterise it based on a single variable. Millets are hardy, plastic crops that grow quickly with little attention. The millets found at the sites investigated by the Land, Water and Settlement project in north-west India are all species native to South Asia (Bates 2016; Bates et al. 2017a, 2017b; Petrie and Bates in press; Petrie et al. 2016, 2017). Today, this northeastern Indus region is highly variable in its environmental conditions, but receives more rainfall in the summer season than the winter, and therefore, even slight changes in the summer rainfall would have had a big impact. At the same time, the winters are cooler but drier, suggesting that rabi (winter sown and harvested) crops may have struggled more than $k$ harif crops. That these millets were present from the earliest periods suggests that people were familiar with the variability of the environment and were using combinations of cereals that were suited to this variability — relying on locally adapted millets as a regular staple supplemented by barley for calories on a less regular basis. As urbanisation and de-urbanisation occurred around them, the rural populations of north-west India continued to grow this hardy crop, indeed as Bates (2016), also Bates et al. (2017a, 2017b), Petrie and Bates (in press), Petrie et al. $(2016,2017)$ have outlined, the proportion of millets increased steadily over time. It is possible that this continuity in millet use relates then not to calories, but to their hardiness as a summer crop suited to the environments of north-west India.

At the same time, however, millets may also have been a marker of local identity. It has long been recognised that food is 

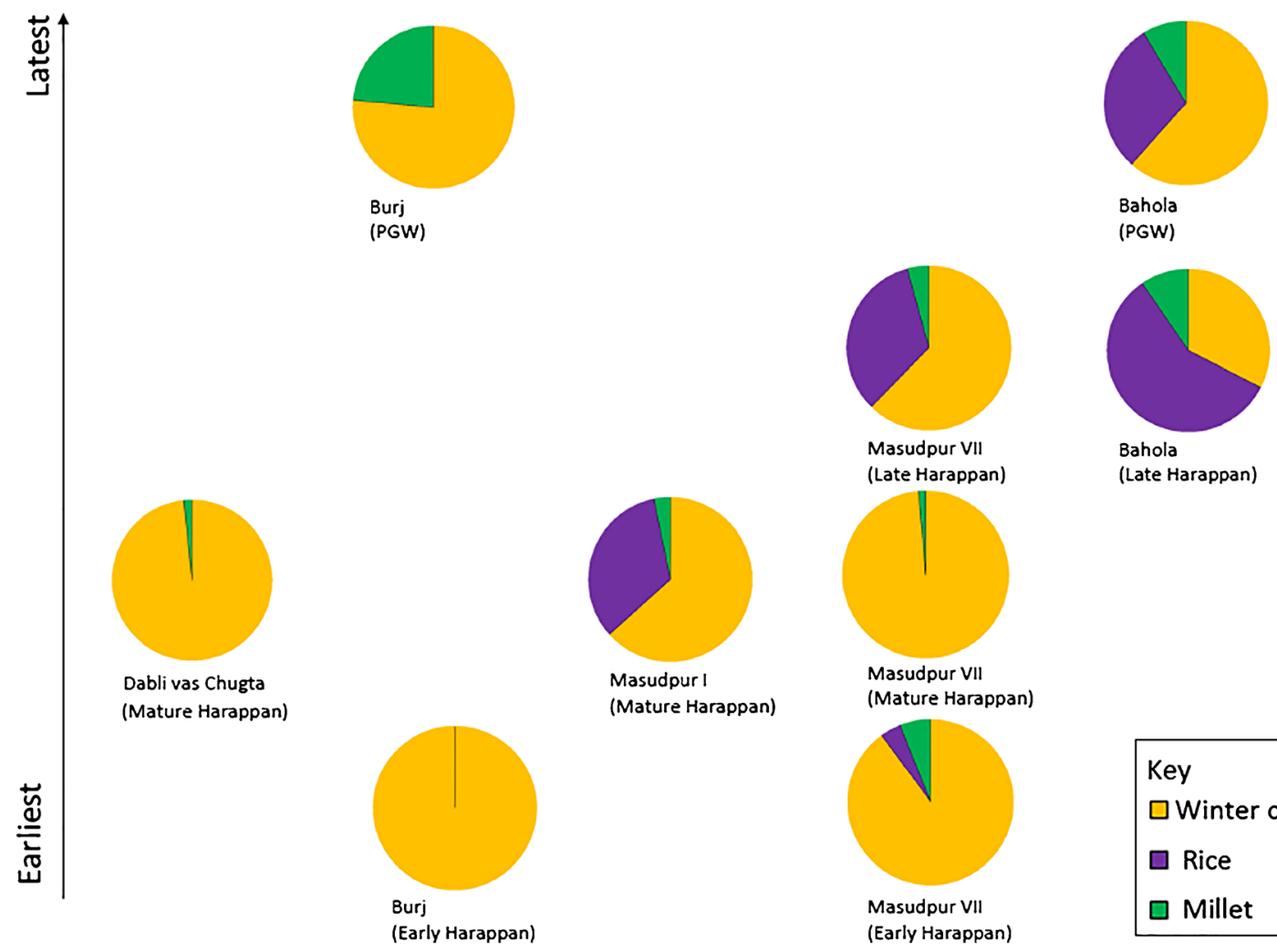

Fig. 8 Proportion of cereal calories organised by period on the $y$-axis and location on the $x$-axis. Wheat, barley and Hordeum/Triticum have been combined to produce a proportion of rabi (winter) cereals shown in orange, rice is shown in purple and millets have been combined and shown in green

an important element of social life (e.g. Appadurai 1981), as it makes statements beyond simple sustenance about identity and affects daily interactions. Cooking methods, for example, can be indicative of a person's origins or ancestry, and food can be linked to social class via differential access to resources, and acts such as feasting can be unifying or divisive. Retaining a local cropping system with regular use of a lower yielding and lower calorific crop may therefore relate not only to environment but may also reflect local identity and choices (e.g. Fuller et al. 2004; Fuller 2005; Smith 2006; Miller 2015). Ethnographic work looking at the functionality of all the cereals used (e.g. documentation of what can be made/when/why/how they are cooked) is a logical avenue for future research.

\section{Conclusions}

This paper used a corpus of Indus archaeobotanical samples to explore a new way of quantifying archaeobotanical data, with the aim of pushing quantification beyond abstracted notions of relative importance. By exploring cereals as calorie providers and using this factor to consider the relative importance of these crops in terms of the daily diet of the people using them, it indicates that different cereals may have been chosen partially for their calorific value. It has also highlighted the likelihood that other aspects such as reliability of cropping and ability to adapt to an unstable environment were also important. For millets, these could have included their drought tolerance, low investment in terms of time and labour, their role in diversifying the economy and as part of risk management strategies (see Petrie and Bates in press, and Bates in prep.). We reiterate that this approach is not meant to replace traditional examinations of density, ubiquity and frequency but should instead be used to enhance the interpretations that can be made from archaeobotanical data. Flotation is becoming more prevalent during excavations at Indus settlements, and as a result, an abundance of data is likely to be collected in future years. Indus archaeobotany therefore needs to push its own boundaries to gain the most out of this new data, by questioning the methods used and what they can tell us about the daily lives and choices of Indus populations. New and even experimental ways of looking at the data are needed, taking into account issues of use, choice and value, in addition to basic quantification to look at intensity, frequency of use and relative importance. Future avenues of research investigating calories, approaches to multicropping to renew the soil nitrogen and mineral contents, cooking techniques, and notions of local values and tastes are all important ways forward. By looking into such areas, we can move beyond simple numbers and ground our data in the behaviour of people in the past. 
Acknowledgments This research was carried out as a part of JB's $\mathrm{PhD}$ research, which was funded by the Arts and Humanities Research Council. Analysis was carried out in the George Pitt Rivers laboratory in the McDonald Institute for Archaeological Research, University of Cambridge. Samples were provided by the Land, Water, Settlement project, co-directed by CAP and RNS, which is a collaboration between the University of Cambridge and Banaras Hindu University that was carried out with the support of the Archaeological Survey of India. The Land, Water, Settlement project was funded by the UK India Education Research Initiative, British Academy Stein Arnold Fund, Isaac Newton Trust, McDonald Institute for Archaeological Research and the Research Councils UK. Additional fieldwork funding for JB was provided by the Arts and Humanities Research Council, Rouse-Ball Research Fund, Cambridge India Partnership Fund, Division of Archaeology Fieldwork Fund and Trinity College Projects Fund. The authors would also like to thank Prof. Martin Jones, Prof. Dorian Fuller, Prof. Marco Madella, Dr. Michele Wollstonecroft and Dr. Rachel Ballentyne for their advice and help.

Open Access This article is distributed under the terms of the Creative Commons Attribution 4.0 International License (http:// creativecommons.org/licenses/by/4.0/), which permits unrestricted use, distribution, and reproduction in any medium, provided you give appropriate credit to the original author(s) and the source, provide a link to the Creative Commons license, and indicate if changes were made.

\section{References}

Ali Y, Atta BM, Akhter J, Monneveux P, Lateef Z (2008) Genetic variability, association and diversity studies in wheat (Triticum aestivum L.) germplasm. Pak J Bot 40:2087-2097

Appadurai A (1981) Gastro-politics in Hindu South Asia. Am Ethnol 8: 494-511

Bates, J. (2016) Social organisation and change in Bronze Age South Asia: a multi-proxy approach to urbanisation, deurbanisation and village life through phytolith and macrobotanical analysis. $\mathrm{PhD}$ Thesis, University of Cambridge.

Bates J, Petrie CA, Singh RN (2017a) Approaching rice domestication in South Asia: new evidence from Indus settlements in northern India. J Archaeol Sci 78:193-201. doi:10.1016/j.jas.2016.04.018

Bates J, Petrie CA, Singh RN (2017b) Exploring Indus crop processing: combining phytolith and macrobotanical analyses to consider the organisation of agriculture in northwest India c. 3200-1500 BC. Veg Hist Archaeobot 26(1):25-41. doi:10.1007/s00334-016-0576-9

Borgerhoff Mulder M., Schacht R. (2012) Human behavioural ecology. John Wiley \& Sons, Ltd, Chichester, UK.

Brookfield HC (1986) Intensification intensified. Archaeol Ocean 21: $177-180$

Fairservis W.A. (1967) The origin, character and decline of an early civilisation. AM MUS NOVITATES no.2302.

Fischler C (1988) Food, self and identity. SOC SCI INFORM 27:275-292

Food and Agriculture Organisation (2014) Grassland species. http://www.fao. org/ag/agp/AGPC/doc/gbase/data/pf000274.htm. Accessed 5 June 2015.

Fuller DQ (2000) The emergence of agricultural societies in South India: botanical and archaeological perspectives. Dissertation, University of Cambridge

Fuller DQ (2002) Fifty years of archaeobotanical studies in India: laying a solid foundation. In: Settar S, Korisettar R (eds) Indian archaeology in retrospect III: archaeology and interactive disciplines. Manohar, New Delhi, pp 247-364

Fuller DQ (2005) Ceramics, seeds and culinary change in prehistoric India. Antiquity 79:761-777

Fuller DQ (2006) Agricultural origins and frontiers in South Asia: a working synthesis. J World Prehist 20:1-86. doi:10.1007/s10963-006-9006-8
Fuller DQ, Korisettar R, Venkatasubbaiah PC, Jones M (2004) Early plant domestications in southern India: some preliminary archaeobotanical results. Veg Hist Archaeobot 13:115-129. doi:10. 1007/s00334-004-0036-9

Fuller DQ, Harvey EL (2006) The archaeobotany of Indian pulses: identification, processing and evidence for cultivation. Environ Archaeol 11:219-246. doi:10.1179/174963106×123232

Fuller DQ, Madella M (2002) Issues in Harappan archaeobotany: retrospect and prospect. In: Settar S, Korisettar R (eds) Indian archaeology in retrospect II: protohistory. Manohar, New Delhi, pp 317-390

Fuller DQ, Rowlands M (2011) Ingestion and food technologies: maintaining differences over the long-term in West, South and East Asia. In: Bennet J, Sherratt S, Wilkinson TC (eds) Interweaving worldssystematic interactions in Eurasia, 7th to 1st millennia BC. Essays from a conference in memory of Professor Andrew Sherratt. Oxbow Books, Oxford, pp 37-60

Fuller DQ, Sato Y-I, Castillo C, Qin L, Weisskopf A, Kingwell-Banham E, Song J, Ahn S-M, van Etten J (2010) Consilience of genetics and archaeobotany in the entangled history of rice. Archaeol Anthropol Sci 2:115-131. doi:10.1007/s12520-010-0035-y

Fuller DQ, Stevens CJ, McClatchie M (2014) Routine activities, tertiary refuse and labour organisation: social inference from everyday archaeobotany. In: Madella M, Lancelotti C, Savard M (eds) Ancient plants and people, contemporary trends in archaeology. University of Arizona Press, Tuscon, pp 174-217

Goody J. (1982) Cooking, cuisine and class: a study in comparative sociology. Cambridge University Press, Cambridge.

Gumerman G IV (1997) Food and complex societies. J ARCHAEOL METHOD TH 4(2):105-139

Hastorf C.A. (2016) The social archaeology of food, thinking about eating from prehistory to the present. Cambridge University Press, Cambridge.

Hastorf C.A. and Popper V.S. (1988) Current palaeoethnobotany: analytical methods and cultural interpretations of archaeological plant remains. University of Chicago Press, Chicago.

Hill K (1988) Macronutrient modifications of optimal foraging theory: an approach using indifference curves applied to some modern foragers. Hum Ecol 16:157-197

Kenoyer JM (1997) Early city-states in South Asia: comparing the Harappan phase and the Early Historic period. In: Nichols DL, Charlton TH (eds) The archaeology of city-states, cross-cultural approaches. Smithsonian Institute Press, Washington D.C., pp 51-70

Kenoyer JM (2000) Wealth and socio-economic hierarchies of the Indus Valley Civilisation. In: Richards J, van Buren M (eds) Order, legitimacy and wealth in early states. Cambridge University Press, Cambridge, pp 90-112

Khatri JS, Acharya M (1995) Kunal: a new Indus-Saraswati site. PURATATTVA 25:84-86

Levi Strauss, C., 1968. L'Origine des maniéres de table. In Mythologiques IV. Seuil, Paris.

Lyons DE, D'Andrea AC (2003) Griddle, ovens and agricultural origins: an ethnoarchaeological study of bread baking in highland Ethiopia. Am Anthropol 105(3):515-530

Madella M (2014) Of crops and food, a social perspective on rice in the Indus Civilisation. In: Madella M, Lancelotti C, Savard M (eds) Ancient plants and people, contemporary trends in archaeology. University of Arizona Press, Tuscon, pp 218-236

Madella M, Fuller DQ (2006) Palaeoecology and the Harappan Civilisation of South Asia: a reconsideration. QUATERNARY SCI REV 25:1283-1301. doi:10.1016/j.quascirev.2005.10.012

Miller HM-L (2015) Surplus in the Indus Civilisation: agricultural choices, social relations, political effects. In: Morehart CT, de Lucia K (eds) Surplus: the politics of production and the Strategies of Everyday life. University Press of Colorado, Colorado, pp 97-120

Miller NF (1988) Ratios in Palaeoethnobotanical analysis. In: Hastorf CA, Popper VA (eds) Current palaeoethnobotany: analytical 
methods and cultural interpretations of archaeological plant remains. Chicago University Press, Chicago, pp 72-85

Minnis PE (1981) Seeds in archaeological sites: sources and some interpretive problems. AM ANTIQUITY 46:143-151

Morrison KD (1994) Intensification of production: archaeological approaches. J Archaeol Method Theory 1:111-159

Parikh D, Petrie CA (2017) Urban-rural dynamics and Indus ceramic production in Northwest India: a preliminary analysis of the pottery from Masudpur I and Masudpur VII. In: Lefevre V, Mutin B, Didier A (eds) South Asian archaeology 2012. Indicopleustoi, Brepols, Turnhout

Pawar V (2012) Archaeological settlement pattern of Hanumangarh District (Rajasthan). Dissertation, MD University Rohtak.

Pearsall D.M. (1989) Palaeoethnobotany: a handbook of procedures. Academic Press, San Diego.

State P (2014) Agronomy Guide 2013-2014 http://extension.psu.edu/ agronomy-guide/average-bushel-weights. Accessed 5 June 2015

Petrie C.A., Bates J. (in press) 'Multi-cropping', intercropping and adaptation to variable environments in Indus South Asia. J WORLD PREHIST

Petrie C.A., Bates J., Higham T., Singh, R.N. (2016) Feeding ancient cities in South Asia: dating the adoption of rice, millet and tropical pulses in the Indus civilisation. ANTIQUITY 90(354): 1489-1504, DOI 10.15184/aqy.2016.210

Petrie C.A., Singh R.N., Bates J., Dixit Y., French C.A.I., Hodell D., Jones P.J., Lancelotti C., Lyman F., Neogi S., Pandey A.K., Parikh D., Pawar V., Redhouse D.I., Singh D.P. (2017) Adaptation to variable environments, resilience to climate change: investigating Land, Water and Settlement in Indus northwest India. CURR ANTHROPOL. DOI: $10.1086 / 690112$

Petrie CA, Singh RN, Singh AK (2009) Investigating changing settlement dynamics on the plains: the 2009 survey and excavations at Masudpur (Hissar District, Haryana). PURATATTVA 39:38-49

Popper VS (1988) Selecting quantitative measures in palaeoethnobotany. In: Hastorf CA, Popper VS (eds) Current palaeoethnobotany: analytical methods and cultural interpretations of archaeological plant remains. Chicago University Press, Chicago, pp 53-71

Possehl, G.L. (1999) Indus Age: the beginnings. University of Pennsylvania Press, Philadelphia, Pennsylvania.

Possehl G.L. (2002) The Indus civilization: a contemporary perspective. AltaMira Press, Walnut Creek.

Reddy S.N. (1994) Plant usage and subsistence modelling: an ethnoarchaeological approach to the Late Harappan of northwest India. Dissertation, University of Wisconsin-Madison.

Reddy SN (1997) If the threshing floor could speak: integration of agriculture and pastoralism during the Late Harappan in Gujarat, India. J Anthropol Archaeol 16:162-187

Reddy S.N. (2003) Discerning palates of the past: an ethnoarchaeological study of crop cultivation and plant usage in India, ethnoarchaeological series. International Monographs in Prehistory, Ann Arbor.

Sherratt A (1991) Sacred and profane substances: the ritual use of narcotics in later Neolithic Europe. In: Garwood P, Jennings D, Skeates R, Toms J (eds) Sacred and profane, monograph 32. Oxford University Committee for Archaeology, Oxford, pp 50-64

Singh R.N., Petrie C.A., Bates J., Pandey A.K., Parikh D., Singh D.P. (2013a) Survey and excavations at Bahola, Karnal District, Haryana: March 27-April 17, 2012. MANAVIKI III-IV:5-11.

Singh RN, Petrie CA, French CAI, Bates J, Pandey AK, Parikh D, Lancelotti C, Redhouse DI (2012) Survey and excavations at Dabli vas Chugta, Hanumangarh District, Rajasthan. PURATATTVA 42:133-147

Singh R.N., Petrie C.A., French C.A.I., Goudie A.S., Gupta S., Tewari R., Singh A.K., Sinha R., Srivastava R.K., Yadav S., Singh V.K. (2008) Settlements in context: reconnaissance in western Uttar Pradesh and Haryana, April and May 2008.) MAN AND ENVIRONMENT XXXIII:71-87.

Singh RN, Petrie CA, French CAI, Neogi S, Pandey AK, Parikh D, Pawar V (2010a) Geoarchaeology survey and excavations at Burj, Fatehabad, Haryana. PURATATTVA 40:94-101
Singh RN, Petrie CA, Joglekar PP, Neogi S, Lancelotti C, Pandey AK, Pathak A (2013b) Recent excavations at Alamgirpur, Meerut District: a preliminary report. MAN AND ENVIRONMENT 38:32-54

Singh RN, Petrie CA, Pawar V, Pandey AK, Neogi S, Singh M, Singh AK, Parikh D, Lancelotti C (2010b) Changing patterns of settlement in the rise and fall of Harappan urbanism: preliminary report on the Rakhigarhi Hinterland Survey 2009. MAN AND ENVIRONMENT XXXV:37-53

Singh RN, Petrie CA, Pawar V, Pandey AK, Parikh D (2011) New insights into settlement along the Ghaggar and its hinterland: a preliminary report on the Ghaggar Hinterland Survey 2010. MAN AND ENVIRONMENT 36:89-106

Smith ML (2006) The archaeology of food preference. Am Anthropol 108:480-493

Sparacino AC, Tano F, Vescovi FD, Sacchi D, Riva N (2002) Preliminary study of the biology of Echinochloa crus-galli and E.colona. In: Hill JE, Hardy B (eds) Proceedings of the second temperate rice conference. IRRI, Los Baños, pp 583-589

Steel MG, Cavers PB, Lee SM (1983) The biology of Canadian weeds 59 Setaria glauca (L.) Beauv. And S. verticilata (L.) Beauv. Can J Plant Sci 63:711-725. doi:10.4141/cjps83-088

Stevens CJ (2003) An investigation of agricultural consumption and production models for prehistoric and Roman Britain. Environ Archaeol 8:61-76. doi:10.1179/env.2003.8.1.61

Twiss K (2012) The archaeology of food and social diversity. J AARCHAEOL RES 20:357-395. doi:10.1007/s10814-012-9058-5

USDA Agricultural Research Service (2014) National nutrient database for standard reference release 27. http://ndb.nal.usda.gov/ndb/foods. Accessed 5 June 2015

Weber S.A. (1989) Plant and Harappan subsistence: an example of stability and change from Rojdi. Dissertation, University of Pennsylvania.

Weber S.A. (1991) Plants and Harappan subsistence: an example of stability and change from Rojdi. Oxford and IBH Publishing Co. Pvt. Ltd., New Delhi.

Weber SA (1992) South Asian archaeobotanical variability. In: Jarrige C (ed) South Asian archaeology 1989. Prehistoric Press, Madison, pp 283-290

Weber SA (1997) Harappa archaeobotany: a model for subsistence. In: Allchin B, Allchin FR (eds) South Asian Archaeology 1995. Oxford and IBH Publishing Co. Pvt. Ltd., New Delhi, pp 115-117

Weber SA (1998) Out of Africa: the initial impact of millets in South Asia. Curr Anthropol 39:267-274. doi:10.1086/204725

Weber SA (1999) Seeds of urbanism: palaeoethnobotany and the Indus Civilisation. Antiquity 73:813-826

Weber SA (2003) Archaeobotany at Harappa: indications for change. In: Weber SA, Belcher WR (eds) Indus ethnobiology: new perspectives from the field. Lexington Books, Lanham, pp 175-198

Weber SA, Fuller DQ (2008) Millets and their role in early agriculture. PRAGDHARA 18:69-90

Weber SA, Kashyap A (2016) The vanishing millets of the Indus civilization. Archaeol Anthropol Sci 8:9-15. doi:10.1007/s12520-013-0143-6

Willcox G (1991) Carbonised plant remains from Shortughai, Afghanistan. In: Renfrew JM (ed) New light on early farming: recent developments in palaeoethnobotany. Edinburgh University Press, Edinburgh, pp 139-153

Willcox G (1992) Some differences between crops of Near Eastern origin and those from the tropics. In: Jarrige C (ed) South Asian Archaeology 1989. Monographs in World Archaeology, Wisconsin, pp 291-300

Winterhalder B, Goland C (1997) An evolutionary ecology perspective on diet choice, risk, and plant domestication. In: Gremillion KJ (ed) People, plants and landscapes: studies in paleoethnobotany. University of Alabama Press, Tuscaloosa, pp 123-160

Wheeler M. (1950) Five thousand years of Pakistan: an archaeological outline. Royal India and Pakistan Society, London.

Wright R.P. (2010) The ancient Indus: urbanism, economy, and society, case studies in early societies. Cambridge University Press, Cambridge. 